\title{
PROFESIONALNA ETIKA KAO IMPERATIV POUZDANOSTI FINANSIJSKOG IZVEŠTAVANJA
}

\author{
Rada Stojanović \\ Savez računovođa i revizora Srbije, Njegoševa 19, Beograd, Srbija
}

\begin{abstract}
Apstrakt:
Kvalitet finansijskih izveštaja kao presudan činilac informacione podrške upravljanja i donošenja poslovnih odluka investitora i drugih korisnika finansijskih izveštaja uslovljen je računovodstvenim standardima, zakonskom regulativom, kontrolom sprovođenja računovodstvenih standarda i zakonske regulative, edukacijom profesionalnih računovođa, računovodstvenom profesijom i etikom i standardima revizije. Osnovna svrha finansijskih izveštaja je obelodanjivanje verodostojnih informacija o finansijskom stanju i performansama privrednog subjekta čime se obezbeđuje poverenje javnosti, koje je bitan činilac tržišne ekonomije, odnosno efektivno odmeravanje i efikasno korišćenje kapitala. Uloga računovođe u savremenim uslovima poslovanja ima polivalentni karakter koji, pored evidentiranja poslovnih transakcija i sačinjavanja finansijskih izveštaja, podrazumeva analizu finansijskih izveštaja, davanje saveta menadžmentu u vezi sa poslovanjem sa hartijama od vrednosti, poresko savetovanje, ostvarivanje komparativnih prednosti, upravljanje finansijskom krizom i minimiziranje rizika u poslovanju, odnosno uloga profesionalnog računovođe usmerena je ka integrisanom izveštavanju. Složenost uloge profesionalnog računovođe u okruženju u kome novac ima predimenzioniran značaj, može da se realizuje samo kroz potpunu posvećenost etici, odnosno uz poštovanje etičkog kodeksa profesionalnih računovođa. Imajući to u vidu, u ovom radu se ističu samo ključni principi etičkog ponašanja profesionalnih računovođa.
\end{abstract}

\author{
Ključne reči: \\ profesionalna etika, \\ profesionalni računovođa, \\ profesionalna regulativa, \\ zakonska regulativa, \\ javni interes.
}

\section{UVOD}

Profesionalne računovođe svoje usluge obavljaju u interesu šire javnosti, bilo da se bave vođenjem poslovnih knjiga i sastavljanjem finansijskih izveštaja ili su angažovani na poslovima revizije, suočeni $s$ jedne strane sa interesima poslodavca za maksimalnim profitom, a sa druge strane sa odgovornošću za profesionalno obavljanje usluga i očuvanje ugleda računovodstvene profesije.

Prema Semjuelu Dž. Broudu (Samuel J. Broad) „Funkcija javnog računovođe u društvu je da pomogne unapređenju poverenja za nesmetan tok poslovne ekonomije; poverenja između zajmoprimca i zajmodavca, dužnika i poverioca, rukovodstva i akcionara, kao i između kupca i prodavca hartija od vrednosti. Ovlašćeni javni računovođa je neustrašiv i nepristrasan čovek, koji poseduje sposobnost da sagleda obe strane pitanja, onaj koji neće dozvoliti da klijent ili suprotne strane izmene njegova časna uverenja; onaj koji diktira i kome nikad ne diktiraju drugi; onaj koji je posvećen svojoj profesiji i koji je iznad prilika za zaradu pomoću sumnjivih sredstava" (Šefers \& Pakaluk, 2009, str. 100 i 104).

Polazeći od činjenice da korisnici finansijskih izveštaja očekuju da finansijski izveštaji odslikavaju finansijsku poziciju entiteta sa tačnošću koja nije realno opravdana, fer prezentaciju finansijskih izveštaja na kojoj insistiraju računovodstveni standardi, treba shvatiti kao koncept prevladavanja suštine nad formom. Kompleksnost ekonomskih aktivnosti i neizvesnost predviđanja budućih događaja imaju za posledicu nemogućnost apsolutno tačnog iskazivanja finansijske pozicije, pre bi se moglo reći da je u pitanju konstantna težnja ka istinitoj i fer aproksimaciji. Slobode koje sadrži računovodstvena regulativa, naročitio u delu profesionalne regulative koja se odnosi na primenu $\mathrm{MSFI}^{1}$, takođe doprinose aproksimaciji finansijskog stanja, kao i ugrožavanju uporedivosti finansijskih izveštaja, koja predstavlja njihovu osnovnu kvalitativnu karakteristiku. Neki od očiglednijih postupaka u kojima se odražavaju slobode su: alternative prilikom vrednovanja određenih bilansnih stavki i primena fer vrednosti; zatim određivanje praga materijalne značajnosti; određivanje, sagledavanje uslova za rezervisanja; tretman događaja nakon datuma izveštavanja; priznavanje prihoda; utvrđivanje upotrebne vrednosti; klasifikacija i reklasifikacija finansijskih instrumenata i sl.

1 Međunarodni standardi finansijskog izveštavanja, koji u okviru termina MSFI podrazumevaju Međunarodne računovodstvene standarde, Međunarodne standarde finansijskog izveštavanja, Konceptualni okvir finansijkog izveštavanja i Tumačenja primene MSFI data od strane Odbora za MSFI. 
Pošto se iz navedenog može zaključiti da Međunarodni standardi finansijskog izveštavanja nisu garant istinitosti i objektivnosti finansijskih izveštaja, pored mera koje preduzima Odbor za međunarodne računovodstvene standarde (IASB - International Accounting Standards Board) kao donosilac standarda, on upućuje i na etičko ponašanje svih učesnika u finansijskom izveštavanju. Konkretizacija i optimiziranje etičkog ponašanja računovođa vrši se primenom etičkog kodeksa profesionalnih računovođa, koji istovremeno doprinosi unapređenju poverenja javnosti u finansijsko izveštavanje. Međunarodna federacija računovođa (IFAC) ${ }^{2}$, odnosno Međunarodni odbor za etičke standarde računovođa, koji svoju aktivnost obavlja u okviru IFAC, je sa ciljem regulisanja računovodstvene profesije na globalnom nivou, kao i obezbeđenja uporedivosti i kvaliteta finansijskih izveštaja, doneo Etički kodeks profesionalnih računovođa koji su njegove članice ili prihvatile za neposrednu primenu ${ }^{3}$ ili su donele nacionalne etičke kodekse čiji je sadržaj usklađen sa ovim kodeksom.

\section{OSNOVE RAČUNOVODSTVENE ETIKE}

Etika je nauka o moralu ${ }^{4}$, koja istražuje smisao i ciljeve moralnih normi, osnovne kriterijume za moralno vrednovanje. U širem smislu, etika se može definisati kao skup moralnih principa ili vrednosti koji su obavezni za pripadnike pojedinih profesija (Milojević, 2007, str. 44). To se posebno odnosi na profesiju lekara i advokata, ali ne u manjoj meri i na računovođe i revizore koji vrše funkciju od javnog interesa. Tradicionalne pofesije su nastale u oblasti medicine ${ }^{5}$, prava $^{6} \mathrm{i}$ teologije $\mathrm{e}^{7}$, dok je profesija u oblasti računovodstva, novijeg doba, odnosno stara je tek oko 170 godina ${ }^{8}$. Osnivačima računovodstvene profesije smatraju se Vilijam Diloit (William Deloitte) koji je osnovao svoju firmu u Londonu 1845. godine, Semjuel Prajs (Semjuel Price) koji se sa Edvinom Voterhausom (Edwin Waterhouse) udružio u partnerstvo 1867. godine i Vilijam Pit (William Peat) koji je započeo svoju praksu takođe 1867. godine. Oni su bili jedni od osnivača prvog profesionalnog udruženja računovođa (Instituta računovodstva) koji je dobio kraljevsku povelju 1880. godine i izvršio prvo profesionalno imenovanje „ovlašćeni računovođa". Prvo profesionalno udruženje u Americi, Institut računovođa i knjigovođa grada Njujorka osnovan je 1882.

2 IFAC danas okuplja 175 članica iz 130 zemalja sveta u okviru kojih je angažovano oko 2,8 miliona članova računovođa iz privrede i javnog sektora.

3 Savez računovoća i revizora Srbije je 2003. godine doneo odluku o direktnoj primeni IFAC-ovog Etičkog kodeksa.

4 Moral je u najširem smislu oblik društvene svesti skup nepisanih pravila, običaja, navika i normi koji su prihvaćeni u životu neke zajednice. Moral određuje kakvo treba da bude ljudsko delovanje; prihvatanjem tih principa od strane društvene zajednice regulišu se međuljudski odnosi. Za razliku od pozitivnih zakona, kršenje moralnih pravila nemaju za posledice pravne sankcije. Kao sankcije nemoralnog ponašanja javljaju se griža savesti, prekor ili bojkot okoline.

5 Oko 4000. godina pre n.e. Hipokrat je formulisao etičku zakletvu lekara koja se smatra prvim profesionalnim etičkim kodeksom.

6 Pravo je dobilo status profesije osnivanjem prvih univerziteta: $u$ Bolonji 1088. godine i u Parizu 1150. godine.

7 Teologija kao sistematsko proučavanje Boga i religije, kod katoličkog sveštenstva stara je oko 1000 godina.

8 Iako je veština evidencija drevna i pored toga što je Luka Pačoli (Luca Pacioli) u 15. veku opisao i ustanovio sistem dvojnog knjigovodstva koji su u to vreme koristili mletački trgovci, a čiji razvoj godine, a prve licence izdao je 1896. godine. S obzirom na to da profesiji računovođa u odnosu na tradicionalne profesije nedostaje istorija i tradicija, podrška etike za nju ima veliki značaj.

Obeležja profesije su da ona obuhvata intelektualne radnje sa velikom pojedinačnom odgovornošću, da obrađuje naučne pretpostavke sa namerom praktične primene, ima edukativno-komunikacijsku tehniku, ima sklonost ka samostalnoj organizaciji i po motivaciji je altruistična ${ }^{9}$. U sociološkom smislu, potrebno je da profesija poseduje standarde za pristupanje, zatim da održava standarde ponašanja, da ima priznat status, da je čine pojedinci asocijacije posvećene napredovanju društvenog značaja profesije i da poseduje tradiciju, običaje i simbole. Drugim rečima, obeležja članova profesije su: posedovanje određenih intelektualnih sposobnosti, pridržavanje zajedničkih pravila ponašanja u pružanju profesionalnih usluga i prihvatanje obaveza prema asocijaciji, poslodavcima i društvu u celini uz težnju ka harmonizaciji ličnih interesa sa širim interesima profesije.

Pošto javnost nije u stanju da ocenjuje kvalitet profesionalnih usluga, ona tu ulogu mora da prepusti samim profesijama, odnosno javnost profesijama treba da prizna njihovu kompetentnost i integritet. Nezavisno od toga što se pojedine odredbe kodeksa različitih profesija mogu međusobno razlikovati, zajedničko im je to da su članovi konkretnih profesija dužni da održavaju viši standard ponašanja od onog koji je propisan zakonom.

\section{KODEKS RAČUNOVODSTVENE PROFESIONALNE ETIKE}

Pošto je osnovna funkcija računovodstvene profesije obezbeđivanje uslova poverenja javnosti, cilju ostvarenja ove funkcije usmereni su i zahtevi pridržavanja kodeksa etičkog ponašanja profesionalnih računovođa. Najmasovnije primenjivani računovodstvenin etički kodeksi u savremenim uslovima poslovanja su Kodeks etike koji je donela profesionalna organizacija Američki institut ovlašćenih javnih računovođa (AICIPA - American Institute of Certified Public Accountants) i Međunarodana federacija računovođa (IFAC - The International Federation of Accountants).

Kodeks etike Američkog instituta ovlašćenih javnih računovođa. Kodeks profesionalne etike koji je doneo AICIPA ima dva osnovna strukturna dela. Prvi njegov deo se odnosi na principe profesionalnog ponašanja pomođu kojih se izražavaju osnovni stavovi o etičkom ponašanju članova profesije. Principi upućuju na etičko ponašanje koje mora biti iznad onog propisanog zakonom, a odnose se na: odgovornost u smislu profesionalnog rasuđivanja; javni interes; integritet; objektivnost i nezavisnost; dužna pažnja; područje i karakter usluge. Drugi deo AICIPA kodeksa odnosi se na pravila ponašanja, on je konkretniji od prvog dela, njega primenjuju samo računovođe koji svoju aktivnost vrše u javnoj praksi. Ovaj deo u svojoj strukturi sadrži celine koje se odnose na: nezavisnost, integritet i objektivnost; obaveznost primene opštih i tehničkih standarda; odgovornost prema klijentima; i ostale odgovornosti i postupanja.

Etički kodeks profesionalnih račuvođa Međunarodne federacije računovođa. Međunarodna profesionalna regulativa obuhvata standarde u oblasti računovodstva, standarde u oblasti revizije, etičke standarde, standarde edukacije, stan-

9 Felxner A. Is Social Work a Profession? (rad prezentovan na konferenciji 1915.) 
darde kontrole kvaliteta, tehničke standarde i informatičke standarde, koji čine ključne instrumente globalizacije finansisjskog izveštavanja. U cilju jačanja poverenja u finansijsko izveštavanje Međunarodna federacija računovođa - IFAC je 2001. godine donela Kodeksa etike profesionalnih računovođa, koji treba da obezbedi uvažavanje fundamentalnih principa profesionalne etike od strane svakog profesionalnog računovođe. $\mathrm{Na}$ osnovu sugestija regulatornih tela korporativnog sektora i u svrhu unapređenja profesionalne etike, kvaliteta revizije i konvergencije sa međunarodnim standardima u oblasti korporativnog upravljanja 2005. i 2009. godine vršeno je revidiranje ovog kodeksa. Osnovni principi IFAC-ovog kodeksa etike su umonogome slični sa principšima AICIPA kodeksa etike, a to su: poštenje, objektivnost, profesionalna osposobljenost i dužna pažnja, poverljivost i profesionalno ponašanje.

Profesionalni etički principi koji treba da budu primenjeni na finansijsko izveštavanje zasnivaju se na izboru kvalitetnih moralnih osobina, zatim na izboru znanja koja se vezuju za obavljanje profesije, korišćenju toga znanja u objektivnom rasuđivanju i zaključivanju, dokazanom poverenju i zahtevom za profesionalno ponašanje. Profesionalne računovođe treba da se pridržavaju osnovnih etičkih principa i da pružaju profesionalne usluge u skladu sa važećim profesionalnim standardima, a poseban disciplinski organ, na osnovu akata o odgovornosti, treba da se stara o slučajevima kršenja i nepoštovanja etičkih normi. Evidentno je takođe, da specifičnosti obavljanja računovodstvenih i revizorskih usluga zahtevaju diferenciranje principa profesionalne etike na one koji se odnose na profesionalne računovođe uopšte i one koji su specifični za profesionalne računovođe u javnoj praksi, odnosno revizore. Stoga je IFAC-ov etički kodeks struktuiran je kao:

- deo A - koji se odnosi na opštu primenu kodeksa,

- deo B - koji se odnosi na profesionalne računovođe u javnoj praksi i

- deo C - koji se odnosi na zaposlene profesionalne računovođe.

\subsection{Opšta primena IFAC-ovog etičkog kodeksa}

Opšti profesionalni etički principi, koji se odnose na sve profesionalne računovođe su u Kodeksu sistematizovani kao: integritet; objektivnost; profesionalna osposobljenost; poverljivost i profesionalno ponašanje.

Princip integriteta. Ovaj princip podrazumeva osnovne moralne osobine koje treba da poseduje profesionalni računovođa u najopštijem smislu: čestitost, poštenje, istinoljublje i fer ponašanje. U kontekstu naznačenih osobina profesionalni računovođa ne treba da ima veze sa prezentovanjem informacija za koje smatra da sadrže netačan ili obmanjujući sadržaj, nepotvrđene izjave ili informacije, odnosno izostavljaju ili prikrivaju informacije za koje se zahteva da su obelodanjene.

Praktično, zadatak profesionalnog računovođe je da obelodani istinu o finansijskim uslovima poslovanja i finansijskoj poziciji entiteta i da na taj način obezbedi uslove poverenja neophodne za tržišnu ekonomiju, pa je iz tih razloga ključno za računovođu da bude opredeljen ka istini. Mark Šefers i Majkl Pakaluk ističu razliku između advokata i računovođe: „Advokat ima dužnost prvenstveno prema svom klijentu i ta ga dužnost često primorava da se koristi sredstvima koja omogućavaju klijentu da izbegne zakon i njegove kazne, ali javni računovođa ima dužnost prema svom klijentu i jav- nosti, a to je da obelodani istinu i samo istinu i ništa osim istine" (Šefers \& Pakaluk, 2009., str. 33).

Princip objektivnosti. Objektivnost kao etički princip, uopšte uzev označava stav koji podrazumeva da se pri izvršavanju postavljenih zadataka u obzir uzimaju samo relevantne informacije, rasuđivanja i mišljenja, na takav način da se može verovati u rezultat rada bez pristajanja na bilo kakve kompromise. Princip objektivnosti sve profesionalne računovođe obavezuje da ne kompromituju profesionalno rasuđivanje zbog pristrasnosti, sukoba interesa ili neprimerenog uticaja drugih lica. Praktično, ovaj profesionalni etički princip označava nepristrasnost, odnosno odsustvo predrasuda, navijačkih opredeljenja ili drugih sličnih uticaja pri rešavanju profesionalnih problema.

Princip profesionalne kompetentnosti i dužne pažnje. Ovaj princip svoje osnovno uporište nalazi u pružanju profesionalnih usluga od strane profesionalno kompetentnih računovođa koji su posvećeni radu u vezi sa kojim primenjuju odgovarajuće tehničke i profesionalne standarde. Profesionalna osposobljenost podrazumeva stručno prosuđivanje u uslovima dinamičkih promena u okruženju, kao i održavanje profesionalne osposobljenosti.

Profesionalna kompetentnost, pored intelektualnih i moralnih vrlina, podrazumeva potpunu posvećenost računovođe profesionalnom pozivu i spremnost na stalno usavršavanje i učenje koje treba da bude usklađeno sa međunarodnim obrazovnim standardima ${ }^{10}$. Prema tome, profesionalni računovođa predstavlja lice koje je član neke IFAC-ove organizacije - članice, koja je ispunila i nastavlja da ispunjava zahteve za očuvanjem profesionalnog zvanja zasnovanog na profesionalnom znanju, veštini, vrednostima i etici.

Dakle, organizovanje profesije računovođa polazi od propisivanja uslova za uključivanje u profesiju nastavlja se sticanjem profesionalnog zvanja, kontinuiranim usavršavanjem i stalnim nadzorom u cilju zaštite javnog interesa i kvalitetnog pružanja usluga uz primenu savremenih tokova u oblasti informacionih tehnologija i zakonodavstva.

Princip poverljivosti. Podaci i informacije do kojih profesionalni računovođa dolazi u svom svakodnevnom radu u okviru profesionalnih ili poslovnih odnosa obično predstavljaju veoma poverljive podatke, često i poslovnu tajnu. ${ }^{11}$ Princip poverljivosti obavezuje profesionalnog računovođu da se uzdržava od obelodanjivanja poverljivih informacija i njihovog korišćenja u svrhu ostvarivanja lične koristi ili koristi za treću stranu. To znači da profesionalni računovođa mora da izgradi poverenje kod poslodavca, odnosno klijenta da će obelodanjivati samo one informacije koje su vezane za

10 Obrazovni komitet IFAC-a vrši razvoj Međunarodnih obrazovnih standarda za profesionalne računovođe - IES (International Education Standards for Professional Accountants), međunarodnih obrazovnih smernica i drugih informacionih dokumenata. Obrazovanje profesionalnih računovođa vrši se prema sledećim standardima:

IES 1 - Uslovi za pristupanje (prijem) programu obrazovanja profesionalnih računovođa,

IES 2 - Sadržaj programa obrazovanja profesionalnih računovođa, IES 3 - Profesionalne veštine,

IES 4 - Profesionalne vrednosti, etika i stavovi,

IES 5 - Zahtevi za praktičnim iskustvom,

IES 6 - Procena profesionalne sposobnosti i kompetentnosti,

IES 7 - Kontinuirano profesionalno usavršavanje,

IES 8 - Zahtevana kompetentnost za profesionalne revizore.

11 Poslovna tajna predstavlja izuzetak od principa javnosti rada, a nju čine isprave i podaci utvrđeni odlukom uprave. Njeno sapštavanje javnosti bi štetilo interesima pravnog lica. Dužnost čuvanja poslovne tajne traje i posle prestanka statusa zaposlenog. 
vršenje profesionalnih usluga u skladu sa standardima profesije. Profesionalne računovođe imaju obavezu da poštuju ovaj princip za vreme obavljanja profesionalnih usluga i nakon završetka ili prekida njihovog obavljanja.

U cilju javnog interesa i interesa profesije etičkim kodeksom se definiše priroda i obim poverljivosti, daju određene smernice i određuju specifične okolnosti u kojima su obelodanjivanja informacija stečenih u toku pružanja profesionalnih usluga dozvoljena ili, čak, obavezna.

Princip profesionalnog ponašanja. Profesionalno ponašanje podrazumeva ponašanje profesionalnih računovođa koje je u skladu sa osnovnim profesionalnim principima, relevantnom regulativom i koje ni na koji način ne može da ugrozi reputaciju profesije niti njeno diskreditovanje, već naprotiv, usmereno je u prilog njene dobre reputacije. Ono se manifestuje i analizira u kontekstu odgovornosti prema klijentima, trećim licima, prema drugim članovima računovodstvene profesije, zaposlenom osoblju i poslodavcima. Poznavanje zakonskih propisa iz oblasti računovodstva, poslovnih finansija, obligacionih odnosa, privrednog prava, radnog prava, spoljnotrgovinkog poslovanja i drugih propisa koji se reflektuju na poslovanje konkretnog poslodavca, kao i poznavanje profesionalne regulative su nužni preduslov principa profesionalnog ponašanja.

Pored toga druga komponenta profesionalnog ponašanja odnosi se na moralne karakteristike profesionalnog računovođe i ponašanje u uslovima izražene oštre konkurencije na tržištu usluga koje pružaju profesionalne računovođe. Ona upućuje na lojalnu konkurenciju, kao način koji podrazumeva aktivnosti marketinga i reklamiranja sopstvenog pružanja usluga, sopstvenih sposobnosti i kvalifikacija na način koji istovremeno ne znači omalovažavanje drugih profesionalnih računovođa.

\subsection{Primena IFAC-ovog etičkog kodeksa od strane računovođa koji obavljaju aktivnosti u javnoj praksi}

Profesionalni računovođa u javnoj praksi je u smislu Kodeksa, profesionalni računovođa nezavisno od njegove funkcionalne klasifikacije, pa se stoga ovaj termin koristi prvenstveno u kontekstu profesionalnog računovođe koji svoju aktivnost obavlja u okviru entiteta koji pruža usluge: revizije, računovodstva, poreskog menadžmenta, konsalting usluga $\mathrm{i}$ usluga finansijskog menadžmenta. Deo B Kodeksa, koji se odnosi na profesionalnog računovođu koji obavlja aktivnost u javnoj praksi, praktično ukazuje na to kako se osnovni profesionalni principi primenjuju na računovođe koji svoju aktivnost obavljaju na tržištu za svoje klijente.

Pretnje poštovanju osnovnih principa mogu da se odnose na lični iteres, samokontrolu, zastupništvo, prisne veze sa klijentom i zastarašivanje od strane klijenta. Lični interes kao pretnja ogleda se u postojanju finansijskog interesa ${ }^{12}$, zatim prekomernoj zavisnosti od naknada jednog klijenta, bliskoj poslovnoj vezi sa klijentom, zabrinutosti zbog mogućnosti gubitka klijenta, postojanju potencijalne mogućnosti zaposlenja kod klijenta ${ }^{13}$.

12 Finansijski interes može da ima oblik učešća u kapitalu ili drugim hartijama od vrednosti, obveznicama, uključujući prava i obaveze sticanja hartija od vrednosti i derivata povezanih sa takvim učešćima.

13 Pretnja takođe može da bude i činjenica da je član angažovanog tima nedavno bio direktor ili član uprave klijenta, zatim da je člana uže porodice ili bliskog srodnika u upravi kod klijenta ili da je bivši partner klijenta, kao i zastrašivanje od strane klijenta u pogledu angažovanja i uslovljavanje naknade povezane sa angažovanjem.
Prihvatanje angažovanja. U vezi sa prihvatanjem angažovanja profesionalni računovođa angažovan u javnoj praksi treba da identifikuje pretnje koje uzrokuju nepoštovanje osnovnih principa, i u tom smislu treba da preduzme zaštitne mere u pravcu sticanja razumevanja prirode poslovanja klijenta, zatim određivanja adekvatnog broja lica angažovanih kod klijenta, korišćenje stručnjaka iz određenih oblasti kada je to neophodno. Poštovanje politika i procedura kontrole kvaliteta u cilju obezbeđenja razumnog uveravanja.

Sukobi interesa. Pretnja poštovanju objektivnosti može nastati i prilikom pružanja usluga klijentima između kojih postoji sukob interesa ili neslaganje u pogledu određenih transakcija. Mere zaštite u tom slučaju su obaveštavanje klijenata o aktivnostima koje mogu predstavljati sukob interesa i pribavljanje njihovog pristanka za angažovanje u takvim okolnostima, odnosno obaveštavanje svih relevantnih strana u vezi sa sukobom interesa, koji se odnosi na delovanje u takvim okolnostima ${ }^{14}$. Ukoliko sukob interesa ne može biti otklonjen primenom zaštitnih mera niti sveden na prihvatljiv oblik, profesionalni računovođa u javnoj praksi treba da odustane od jednog ili više konfliktnih angažovanja.

Dodatna mišljenja. Postoje okolnosti u kojima se od profesionalnog računovođe u javnoj praksi traži da pruži dodatna uveravanja, odnosno mišljenje o poštovanju određenih standarda i procedura kod entiteta koji je klijent drugog profesionalnog računovođe u javnoj praksi. Pretnja po pitanju profesionalne osposobljenosti i dužne pažnje u ovakvim okolnostima može da nastane, ako profesionalni računovođa angažovan u svrhu dodatnog mišljenja nema na raspolaganju iste činjenice relevantne za izražavanje profesionalnog mišljenja kao i profesionalni računovođa koji je prvobitno dao mišljenje u vezi sa predmetnim procedurama i transakcijama. U slučaju da je komunikacija sa aktuelnim računovođom u javnoj praksi onemogućena, profesionalni računovođa treba da razmotri da li je uputno davanje dodatnog mišljenja.

Naknade i druga nagrađivanja. Pretnja u pogledu profesionalne osposobljenosti i dužne pažnje može da nastane kada je iznos tražene naknade toliko nizak da može uzrokovati teškoće u izvršenju angažovanja u skladu sa profesionalnim standardima. Značaj pretnji koje uzrokuju nepoštovanje objektivnosti po osnovu ličnog interesa zavisi od: prirode angažovanja; raspona između mogućeg iznosa naknade; određivanja naknade i činjenice da li će ishod transakcije pregledati treća strana. Mere zaštite u ovom slučaju obuhvataju: unapred sačinjen pisani ugovor u vezi sa izračunavanjem naknade; obelodanjivanje informacije o poslu koji je obavio profesionalni računovođa i osnovi izračunavanja naknade. U određenim okolnostima naknada može da predstavlja indirektnu naknadu po osnovu upućivanja stalnog klijenta na drugog profesionalnog računovođu u javnoj praksi ili pak provizuju po osnovu posredovanja. ${ }^{15}$

Reklamiranje profesionalnih usluga. ${ }^{16}$ Prilikom promovisanja posla putem reklamiranja ili drugih oblika marketin-

14 U slučaju da ne dobije pristanak od strana kod kojih postoji sukob interesa, profesionalni računovođa u javnoj praksi treba da odustane od angažovanja kod druge strane (ili strana) u vezi sa kojom postoji sukob interesa.

15 Na primer, provizija može biti naplaćena od prodavca informacione opreme ili kompjuterskog programa po osnovu prodaje klijentu. Pošto takve naknade mogu da predstavljaju pretnje poštovanju osnovnih etičkih principa profesionalni računovođa treba da preduzme zaštitne mere koje podrazumevaju informsanje klijenta o svim dogovorima u vezi sa plaćanjem i naplatom provizije

16 Reklamiranje se etičkim Kodeksom definiše kao javno objavljivanje informacija u vezi sa uslugama ili veštinama u javnoj praksi koje se vrši u okviru poslovanja. 
ga, ukoliko se usluge reklamiraju tako se preuveličavaju tvrdnje u vezi sa: kvalitetom usluga, kvalifikacijama i iskustvima koje se poseduju ili vrše omalovažavajuća povezivanja putem poređenja sa radom drugih, može da postoji potencijalna pretnja poštovanju osnovnih principa, pa profesionalna organizacija treba da pruži krajnji sud o podobnosti određenih oblika reklamiranja profesionalnih usluga.

Pokloni i gostoprimstva. Nuđenje poklona ili činjenje gostoprimstva profesionalnom računovođi u javnoj praksi predstavlja pretnju objektivnosti po osnovu ličnog interesa, a u vezi sa tim može da postoji i pretnja zastrašivanja usled pretnje objavljivanja takvih poklona u javnosti.

Raspolaganje imovinom klijenta. Držanje imovine klijenta ima za posledicu pretnju poštovanju principa objektivnosti po osnovu ličnog interesa. Mere zaštite u takvim okolnostima su čuvanje poverene imovine sa odgovarajućom odgovornošću odvojeno od lične imovine, upotreba preuzete imovine samo u predviđene svrhe, mogućnost pravdanja i pružanja uvida u imovinu u svakom trenutku. Pretnje naročito mogu da nastanu u vezi sa poreklom držane imovine, ukoliko je ona stečena nelegalnim aktivnostima, kao što je pranje novca.

Objektivnost. Postojanje interesa ili veza sa klijentom, rukovodiocima ili zaposlenima kod klijenta može da predstavlja pretnju principu objektivnosti. Nezavisnost uma i delovanja je neophodan uslov zaključaka uveravanja bez pristrasnosti, konflikta interesa ili preteranog uticaja drugih. Ukoliko su prisutne pretnje poštovanju objektivnosti, profesionalni računovođa treba da proceni njihov značaj, odredi mere zaštite $\mathrm{u}$ cilju njihovog svođenja na prihvatljiv nivo. Mere zaštite, $\mathrm{u}$ zavisnosti od specifičnih okolnosti, mogu da podrazumevaju: procedure nadzora, diskusiju o problemu sa višim rukovodiocima revizorske firme i sa rukovodiocima klijenta, okončanje finansijske ili poslovne veze koja uzrokuje pretnju i povlačenje iz tima koji radi na angažovanju.

Zaštitne mere po osnovu pretnji poštovanju opštih principa propisanih za profesionalnog računovođu koji aktivnost obavlja u javnoj praksi mogu da imaju oblik: zaštitnih mera kreiranih od strane profesije, odnosno zakonske regulative ili zaštitnih mera zaštite na nivou radnog okruženja.

Zaštitne mere kreirane od strane profesionalne i zakonske regulative obuhvataju zahteve obrazovanja i iskustva čije je ispunjenje neophodno da bi se pristupilo profesiji; zatim kontinuirana edukacija; regulativa iz oblasti korporativnog upravljanja; profesionalni standardi; profesionalni nadzor i disciplinski postupci i eksterni pregledi izveštaja, obrazaca i informacija sačinjenih od strane profesionalnih računovođa.

U okviru radnog okruženja revizorskog preduzeća ili drugog preduzeća koje pruža usluge uveravanja, zaštitne mere usmerene na poštovanje opštih principa etičkog kodeksa za profesionalne računovođe u javnoj praksi imaju oblik internih politika i procedura usmerenih na identifikovanje pretnji koje uzrokuju nepoštovanje osnovnih principa i određivanja zaštitnih mera koje ove pretnje svode na prihvatljiv nivo. Zaštitne mere u radnom okruženju revizorske kuće ili drugog entiteta koji pruža usluge uveravanja povodom specifičnog angažovanja mogu da se odnose na: angažovanje dodatnog profesionalnog računovođe radi saveta ili pregleda obavljenog posla; konsultovanje nezavisne treće strane; diskusija o etičkim pitanjima sa upravom klijenta; obelodanjivanje prirode usluga koje se vrše i naknada za te usluge licima koja su uprava klijenta; angažovanje druge firme da obavi deo angažovanja ili ponovno angažovanje; rotiranje višeg tima koji pruža usluge revizije ili druge usluge uveravanja.
Nezavisnost kao ključni princip profesionalnih računovođa u javnoj praksi. Nezavisnost je osnovni uslov za poštovanje principa objektivnosti, odnosno nezavisnost je prvi uslov za objektivnost ovlašćenih javnih računovođa. Iako nezavisnost nije moguće precizno definisati, njena suština je da predstavlja izraz profesionalnog integriteta pojedinca. Profesionalni računovođa u javnoj praksi pre izražavanja svog mišljenja o finansijskim izveštajima, ima obavezu da oceni svoj odnos prema klijentu, radi utvrđivanja da li bi mogao da očekuje da neko ko je upoznat sa svim činjenicama njegovo mišljenje smatra nezavisnim.

Angažovanja na osnovu kojih se pruža uveravanje, koje prevashodno uključuje angažovanje na reviziji finansijskih izveštaja, imaju za cilj povećanje nivoa poverenja ciljnog korisnika. U vezi sa angažovanjem uveravanja primenjuju se određeni kriterijumi u zavisnosti od predmeta uveravanja ${ }^{17}$. Međutim, ukoliko profesionalni računovođa u javnoj praksi nije nezavisan pri formiranju mišljenja prestaje osnovna potreba za njegovim uslugama ${ }^{18}$.

Nezavisnost kao princip je etičkim Kodeksom definisana kao dvoslojna karakteristika koja podrazumeva: nezavisnost uma i nezavisnost delovanja. Nezavisnost uma, odnosno načina mišljenja, je stanje uma koje omogućava izražavanje zaključaka oslobođenih uticaja koji može ugroziti objektivnost profesionalnog rasuđivanja i profesionalni skepticizam, a koje istovremeno dozvoljava pojedincu da deluje sa integritetom. Nezavisnost delovanja podrazumeva izbegavanje činjenica i okolnosti koje su toliko značajne da bi na osnovu njih razumna i obaveštena treća strana koja poznaje sve relevantne informacije uključujući i primenjene mere zaštite razumno zaključila da je ugrožen integritet, objektivnost ili profesionalni skepticizam prilikom angažovanja na osnovu koga se pruža uveravanje.

Praktično, nezavisnost delovanja se ispoljava u tri faze: najpre kao nezavisnost ispitivanja, koja se vezuje za odsustvo pritisaka i drugih uticaja pri izboru oblasti aktivnosti, odnosa i politika menadžmenta, a odnosi se na obuhvatnost odnosno dostupnost relevantnih informacija (Novićević, 2006). Sledeća faza ostvarivanja nezavisnosti je nezavisnost kreiranja programa ispitivanja, koja se vezuje za slobodu izbora tehnika i procedura ispitivanja, odnosno samostalnost ovlašćenog javnog računovođe, odnosno ovlašćenog revizora u razvijanju programa ispitivanja postavljenog u fazi planiranja. Treća faza nezavisnosti predstavlja nezavisnost izveštavanja, koja se vezuje za odsustvo pritisaka i drugih uticaja koji imaju za cilj promenu saznanja do kojih je ovlašćeni javni računovođa došao tokom svojih ispitivanja. Navedene dimenzije nezavisnosti moraju biti realizovane u celini, da bi zavisnost suštinski postojala.

Članovi timova koji su angažovani na uslugama uveravanja takođe treba da sagledaju potencijalne pretnje nezavisnosti po osnovu svih osnovnih principa koji su dati u delu A etičkog

17 U zavisnosti od predmeta uveravanja kriterijumi mogu biti: Međunarodni standardi revizije (ISA); Međunarodni standardi o ispitivanju angažovanja (ISRE); Međunarodni standardi angažovanja na osnovu kojih se pruža uveravanje (ISAE) ili neki od okvira za ocenu efektivnosti interne kontrole (COSO ili CoCo).

18 Potrebno je da nezavisnost revizora bude zastupljena ne samo prilikom pružanja usluga revizije, već i prilikom pružanja drugih usluga: vođenja poslovnih knjiga i sastavljanja finansijskih izveštaja; procene vrednosti imovine, obaveza i kapitala; računovodstvenog i poreskog konsaltinga; konsaltinga u oblasti strateškog i finansijskog menadžmenta; razvoja i implemantacije informacionih sistema za obradu računovodstvenih podataka i sl. 
Kodeksa ${ }^{19}$, da izvrše procenu konkretnih okolnosti, prirode angažovanja, a zatim i prirodu zaštitnih mera, kao što su: odluka o prihvatanju angažovanja, odluka o tome da li treba angažovati određenog zaposlenog na konkretnom projektu i slično. Tom prilikom, uzima se u obzir javni interes, koji imaju entiteti kao rezultat svog poslovanja, veličine ili korporativnog statusa (kompanije kotirane na berzi, kreditne institucije, osiguravajuća društva i penzioni fondovi) na koje je upućrn širok krug stekholdera ${ }^{20}$.

Procena pretnji nezavisnosti treba da se vrši pre prihvatanja angažovanja, kako bi bila potkrepljena odgovarajućim dokazima i praćena određivanjem mera zaštite. Pošto je pitanje nezavisnosti veoma osetljivo i ne može se na njega primeniti univerzalni model zaštite, IFAC-ov etički kodeks za profesionalne računovođe paragrafima od 290.1 do 290.214. daje uputstva u vezi sa identifikovanjem pretnji nezavisnosti koja su ilustrovana brojnim primerima koji ukazuju na moguće situacije otklanjanja pretnji nezavisnosti i njihovo svođenje na prihvatljiv nivo.

Smatra se da ovlašćeni javni računovođa mora da poseduje dva oblika nezavisnosti i to nezavisnost $u$ stvari i nezavisnost na izgled. Nezavisnost $u$ stvari se odnosi na objektivnost, na osobinu da se na njega ne može uticati po pitanju lične dobiti. Nezavisnost na izgled označava njegovu oslobođenost od potencijalnih sukoba interesa koji bi mogli da ugroze poverenje koje javnost ima u njegovu nezavisnost $u$ stvari.

Kod profesionalnih računovođa koji vrše usluge revizije posebno je interesantno pitanje da li su interesi računovođa koji obavljaju usluge revizije i investitora povezani. Klijent plaća usluge revizije, a mišljenje revizora, praktično nije od koristi klijentu, već široj javnosti, odnosno potencijalnim investitorima. Altruizam ${ }^{21}$ računovodstvene profesije nadilazi altruizam kod drugih profesija, zbog toga što profesionalni računovođa (naročito onaj koji pruža usluge revizije) obično pruža usluge licima koja su mu nepoznata (javnost), kao i zbog toga što računovođa mora da bude spreman da se pre odrekne svojih prihoda nego da uradi nešto nečasno, odnosno mora da bude spreman da prekine angažman ako nije u stanju da ispoštuje etičke principe.

\subsection{Primena IFAC-ovog etičkog kodeksa od strane zaposlenih računovođa}

Zaposleni profesionalni računovođa, u smislu Kodeksa, je zaposleni profesionalni računovođa koji je zaposlen kod poslodavca u oblastima kao što su trgovina, usluge, javni sektor, obrazovanje regulatorna tela ili profesionalna tela ili profesionalni računovođa koji radi po ugovoru sa pravnim licima. Deo Kodeksa označen kao C ilustruje način primene osnovnih etičkih principa na profesionalne računovođe zaposlene kod poslodavca. Nezavisno od pravne forme ugovora sa entitetom u kome je profesionalni računovođa zaposlen

19 Pretnje nezavisnosti po osnovu: integriteta, objektivnosti profesionalne osposobljenosti i dužne pažnje, poverljivosti i profesionalnog ponašanja.

20 Preduzeće može da se posmatra kao koalicija većeg broja interesnih grupa: vlasnika kapitala, menadžera, zaposlenih, kupaca, dobavljača, bankara i drugih. Između članova koalicije na jednoj strani, preduzeća kao organizacije, na drugoj strani postoji dihotomija interesa. Cilj i jedne i druge strane je zadovoljavajuća i maksimirajuća funkcija cilja. Zadatak menadžera je: da formulišu ciljeve preduzeća koji su često u suprotnostima sa ciljevima grupa i da donesu odluke koje vode realizaciji tih ciljeva.

21 Altruizam: osobina koja podrazumeva spremnost da se pomogne drugima, zbog njih samih, a ne zbog nadoknade koja se očekuje. (rukovodeća pozicija, partner ili angažovanje na izvršnim poslovima) na identičan način se primenjuju etičke norme, a etičkim Kodeksom se razmatraju i okolnosti u kojima može da dođe do konflikta u odnosu na njih.

Zaposleni profesionalni računovođa po pravilu treba da podržava ciljeve i procedure koje je ustanovio poslodavac i pri tome može da bude izložen pritiscima da deluje suprotno zakonima i regulativi, suprotno tehničkim standardima, zatim da omogući sticanje neetičke i nezakonite zarade rukovodstvu, da namerno obmanjuje revizora i regulatorna tela, da u značajnoj meri iskrivljuje činjenice u finansijskim izveštajima, poreskoj prijavi i sl.

Prema tome, pretnje osnovnim etičkim principima za zaposlenog računovođu mogu da budu:

- lični interes (finansijski interes, nedozvoljeno korišćenje imovine entiteta za lične svrhe, zabrinutost za sigurnost zaposlenja),

- samokontrola (poslovne odluke kontroliše zaposleni koji je odgovoran za njihovo donošenje),

- zastupanje (unapređenje ciljeva entiteta mogu promovisati profesionalne računovođe, čak i ukoliko ne koriste obmanjujuće izjave),

- prisnost (dugotrajna saradnja sa poslovnim partnerima koji utiču na poslovne odluke, prihvatanje poklona i povlašćenog tretmana) $i$

- zastrašivanje (pretnja otpuštanja ili smenjivanja zaposlenog profesionalnog računovođe).

Zaštitne mere povodom pretnji osnovnim etičkim principima ustanovljene su od strane profesije i zakonodavca ili pak od strane radnog okruženja.

Zaštitne mere ustanovljene etičkim principima upućuju na to da profesionalni računovođa treba da razmotri relevanthe činjenice u vezi sa rešavanjem konflikata, zatim osnovne principe koji utiču na konkretni problem; da utvrdi interne procedure i alternativne planove delovanja.

Zaštitne mere ustanovljene od strane preduzeća mogu da se odnose na: pojačan sistem korporativnog nadzora, procedure zapošljavanja, adekvatne interne kontrole i nadzor kvaliteta rada zaposlenih, edukaciju zaposlenih, podsticaj komunikacije sa višim nivoima uprave bez bojazni odmazde, konsultovanje sa drugim profesionalnim računovođom.

Pripremanje i prezentovanje finansijskih informacija i upravljačkih informacija profesionalni računovođa treba da vrši pošteno i u skladu sa relevantnim profesionalnim standardima, tako da se njima jasno opisuje priroda poslovnih transakcija, imovine i obaveza. Informacije treba da budu date pravovremeno i na odgovarajući način, činjenice treba da budu date precizno i potpuno po svim važnim aspektima. U slučaju kada nije moguće umanjenje pretnje zaposleni profesionalni računovođa treba da odbije da dalje bude povezan sa obmanjujućim informacijama, zatim da razmotri da li postoji potreba da se obaveste nadležni organi, da zatraži pravni savet ili eventualno ostavku.

Etičkim merama se takođe, ističe da zaposleni profesionalni računovođa ne treba da manipuliše informacijama, niti da poverljive informacije koristi za ostvarenje lične dobiti.

\section{UTICAJ KORPORATIVNE ETIKE NA KVALITET FINANSIJSKOG IZVEŠTAVANJA}

Suština koncepta odgovornog poslovanja privrednih društava zasnovana je na: profitabilnosti, etičnosti i društvenoj 
odgovornosti. Menadžment izborom računovodstvenih politika i politike finansijskog izveštavanja direktno utiče na kvalitet informacija sadržanih u finansijskim izveštajima poslovnog subjekta. Ove činjenice opredeljuju odgovornost menadžmenta za tačnost finansijskih izveštaja, što je u direktnoj vezi sa poslovnom etikom menadžera. Na etičko ponašanje menadžera utiču brojni faktori, od kojih su najizraženiji: individualne karakteristike (lične vrednosti, individualnost, moć samokontrole); strukturne varijable (formalna pravila i propisi, ponašanje nadređenih, nagrade, pritisci i drugo), sadržaj i snaga organizacione kulture. Menadžment prilikom opredeljenja za računovodstvene politike treba da ima u vidu: finansijski položaj konkretnog poslovnog subjekta, disperziju vlasništva nad poslovnim subjektom, stepen internacionalizacije poslovanja tog poslovnog subjekta i njegovu veličinu.

Odgovornost menadžmenta za finansijsko izveštavanje zasnovana na smernicama MRS 1, kao i na odredbama Direktive EU 2013/34, kao i činjenica da su finansijski izveštaji javni dokument, dovoljan su dokaz o neophodnosti etičkog ponašanja menadžmenta u pogledu finansisjkog izveštavanja. Sami finansijski izveštaji predstavljaju jedan od instrumenata kontrole kvaliteta poslovnih odluka menadžmenta i zaštite interesa poverilaca. Činjenica da je u određenim okolnostima prisutno nepoverenje u odnosima između korisnika finansijskih izveštaja, menadžmenta, i nezavisnih revizora zbog sukoba interesa predstavlja moguću pretnju kvalitetu finansijskih izveštaja. U takvim okolnostima etika dobija na značaju, kao osnovna prednost u poslovanju i etičko ponašanje kao najbolji dugoročni interes menadžmenta, korisnika finansijskih izveštaja i nezavisnih revizora.

Sukob interesa koji često značajno ugrožava aktivnosti menadžmenta postoji u onim okolnostima kada pojedinac mora da se odluči da li će delovati u pravcu sopstvenih interesa, interesa kompanije ili interesa određene treće strane. Najčešće relacije u kojima se ispoljava sukob interesa su odnosi: zaposleni-kompanija; kompanija - poslovno okruženje; kompanija - konkurenti i sl. U kontekstu kvaliteta finasijskih izveštaja relevantan je sukob interesa između menadžmenta sa jedne strane i vlasnika kapitala i revizora sa druge strane. Menadžment ima odgovornost za sastavljanje finansijskih izveštaja na osnovu kojih vlasnici kapitala sagledavaju efikasnost upravljanja kapitalom koji je poveren menadžmentu. $\mathrm{Na}$ osnovu efikasnosti upravljanja poverenim sredstvima vlasnici kapitala sagledavaju mogućnost opstanka, vrše projekciju budućeg poslovanja kompanije i određuju visinu materijalne satisfakcije menadžmenta. Ovaj sukob interesa ${ }^{22}$ sastoji se u mogućim težnjama menadžmenta koji je odgovoran za finansijsko izveštavanje, da prikaže nerealno poslovanje u cilju obezbeđivanja veće materijalne satisfakcije, što je jedan od motiva vlasnika kapitala za angažovanjem eksternih revizora koji verifikuju finansijske izveštaje potpisane od strane menadžmenta. Mnogi etičari poput Henry Sidgwick-a, osnovnu ulogu etike vide upravo u pomirenju i harmonizaciji sukobljenih interesa.

Stav poslovnog subjekta u odnosu na etiku, odnosno etička klima u poslovnom subjektu u direktnoj je vezi sa društvenom odgovornošću menadžmenta. Društvena odgovornost može biti definisana kao: odnos menadžmenta prema okru-

$22 \mathrm{U}$ oblasti revizije primer za sukob interesa je situacija u kojoj se našla revizorska firma Artur Andersen koja za kpompaniju Waste Management Inc. Prihvatila angažovanje na poslovima nezavisne revizije finansijskih izveštaja, iako je za istu kompaniju pružala usluge konsaltinga. ženju, koji se meri pisanim ili nepisanim moralnim pravilima, prema kojima se ocenjuje ponašanje menadžmenta, odnosno preduzeća koje on vodi. Ona takođe može biti predstavljena u vidu sledeće hijerarhije:

- filantropska odgovornost (doprinos zajednici i kvalitetu života);

- etička odgovornost (poštovanje moralnih pravila i prihvaćenih normi ponašanja);

- ekonomska odgovornost (posvećenost ostvarivanju vrednosti, profitabilnosti i uvećanju ekonomskog bogatstva).

Kvalitet finansijskih izveštaja u direktnoj je vezi sa etičkom i sa zakonskom odgovornošću i ukoliko donosioci odluka zanemaruju etičku odgovornost javljaju se zloupotrebe koje iako ne dovode do kršenja zakonske odgovornosti, rezultiraju „iskrivljenom slikom” o poslovnom subjektu putem netačnih podataka i nepotpunih informacija u finansijskim izveštajima, što može da ima odlike kreativnog računovodstva.

Značaj etike uočen je od strane vodećih svetskih kompanija što je rezultiralo posebnim programima za implementaciju etičkog ponašanja menadžmenta. Svest o značaju korporativne etike u Srbiji potvrđuje činjenica da je Privredna komora Srbije usvojila Kodeks poslovne etike, koji je objavljen u Službenom glasniku RS, br. 1/2006, kao i činjenica da je Udruženje korporativnih direktora u 2007. godini usvojilo etički kodeks. Brojna privredna društva u Srbiji, kao što su NIS, Beogas i druga imaju usvojen kodeks poslovne etike koji obavezuje sve zaposlene.

\section{UTICAJ IGNORISANJA ETIKE U ZAKONSKOJ REGULATIVI U SRBIJI NA FINANSIJSKO IZVEŠTAVANJE}

Aktuelnom zakonskom regulativom u oblasti računovodstva, odnosno revizije i postojanjem posebnog zakona za računovodstvo i posebnog zakona za reviziju, neopravdano je izvršeno deljenje računovodstvene profesije jer računovođe i revizori predstavljaju jedinstvenu profesiju, odnosno radi se samo o različitim specijalizacijama iste profesije.

Osnovni nedostatak aktuelnih zakonskih propisa u pogledu etike je činjenica da Zakon o računovodstvu (Sl. glasnik RS, br. 62/13) ne prepoznaje niti računovodstvenu profesiju niti etički kodeks profesionalnih računovođa, dok Zakon o reviziji (Sl. glasnik RS, br. 62/13) IFAC-ov etički kodeks profesionalnih računovođa, naziva Kodeksom profesionalne etike revizora. Radi se o jedinstvenom IFAC-ov etičkom i kodeksu profesionalnih računovođa, za čiju se direktnu primenu opredelio Savez računovođa i revizora Srbije, a deo B ovog kodeksa se odnosi na revizore, kao profesionalne računovođe u javnoj praksi.

Očigledno je kakve će posledice izazvati navedene odredbe u pogledu kvaliteta finsijkih izveštaja, kada finansijske izveštaje može da sačini bilo koje lice, nezavisno od toga da li poseduje određene kvalifikacije i profesionalno iskustvo, pri čemu lice koje sastavlja finansijske izveštaje nema odgovornost u vezi sa sastavljanjem tih izveštaja, kako ličnu, jer ne potpisuje finansijske izveštaje, tako ni profesionalnu, jer ne mora da primenjuje etički kodeks profesije kojoj bi trebalo da pripada. Kada navedene negativne posledice postanu vidljive verovatno će biti kasno za njihovo otklanjanje.

Pored naznačenih osnovnih nedostataka računovodstvene regulative, nedostatak je i u tome što pravana lica razvrstana 
kao mala pravna lica i kao mikro pravna lica nemaju mogućnost da primenjuju MSFI ${ }^{23}$.

Slobode koje sadrži računovodstvena regulativa, naročito $\mathrm{u}$ delu profesionalne regulative, koja se odnosi na primenu MSFI, doprinose aproksimaciji finansijskog stanja odnosno ugrožavanju tačnosti, kao i uporedivosti finansijskih izveštaja.

Fer vrednost, koja je prisutna u smernicama MSFI i u određenoj meri u smernicama MSFI za MSE omogućava da se korisnicima finansijskih izveštaja prezentuju podaci o tome kolika je bruto fer vrednost materijalnih ulaganja, kao i podaci o iznosu revalorizacionih rezervi. Pored ovih ključnih informacija konceptom fer vrednosti obezbeđuje se i podatak o fer vrednosti akumulirane amortizacije, odnosno posrednim putem se obezbeđuje podatak o neto fer vrednosti materijalne imovine.

Pošto MSFI i MSFI za MSE sami po sebi ne predstavljaju garant objektivnosti finansijskih izveštaja, tek oslanjanjem na etiku, u opštijem kontekstu koji uključuje kako etiku profesionalnih račuvođa, tako i poslovnu etiku, mogu se očekivati respektabilni rezultati efektivne primene koncepta fer vrednosti. Činjenica da je odnos prema poslovnoj etici u Srbiji prepušten usmeravanjima poslovnih praksi pojedinačnih entiteta i njihovih shvatanja poslovne etike, kao i činjenica da aktuelna zakonska računovodstvena regulativa u Srbiji ignoriše računovodstvenu profesiju i etiku profesionalnih računovođa, ne doprinose unapređenju kvaliteta finansijskog izveštavanja.

Navedeno upućuje na potrebu preispitivanja zakonske računovodstvene regulative, njenog usklađivanja sa međunarodnom profesionalnom regulativom i sa Direktivom 2013/34 EU i usmeravanja ka kvalitetu finansijskog izveštavanja uz uvažavanja profesije u računovodstvu i etike kao ravnopravnih činilaca kvaliteta finansijskog izveštavanja, pored zakonske regulative; profesionalne regulative; nadzora, praćenja, obrazovanja i obuke. Tim pre što u Srbiji postoji profesionalna asocijacija, Savez računovođa i revizora Srbije, čija aktivnost postoji već šest decenija i koji je od 1997. godine aktivna članica IFAC-a, zatim članica je Evropske asocijacije računovođa, kao i regionalnih asocijacija računovođa kao što je Mediteranaska asocijacija računovođa i Asocijacija računovođa jugoistočne Evrope. Savez po osnovu svojih članskih obaveza i prava pored prevođenja međunarodne profesionalne regulative, u okviru koje i IFAC-ovog etičkog kodeksa profesionalnih računovođa, vrši organizovanje ispita za sticanje profesionalnih zvanja, organizuje kontinuiranu edukaciju svojih profesionalnih članova, vrši kontrolu kvaliteta njihovih profesionalne usluga i nadzor nad primenom etičkih principa.

Uvođenjem etike i profesije u zakonsku regulativu bila bi ozakonjena primena etičkih zahteva IFAC-ovog etičkog kodeksa profesionalnih računovođa i uspostaljeni konkretniji mehanizmi usmereni na pouzdanost informacija sadržanih u finansijskim izveštajima i načinjen korak ka osnovnim pretpostavkama vraćanja poverenja u finansijsko izveštavanje.

\section{ZAKLJUČAK}

U razvijenim kulturama finansijskog izveštavanja i računovodstva opšte je prihvaćeno stav da kvalitetno finansijsko izveštavanje doprinosi ekonomskom razvoju i prosperitetu

23 Ovaj nedostatak naročito se očituje u okolnostima vezanim za konsolidovanje, kada u krug konsolidovanja ulaze mala pravna lica i mikro pravana lica, za potrebe konsolidovanja moraju da se sastav- nacionalne, regionalne i svetske ekonomije. Posredstvom tržišta kapitala, odnosno alokacijom ograničenih finansijskih resursa realizuje se ova makroekonomska funkcija finansijskog izveštavanja. Isto tako, prezentacija i obelodanjivanje finansijske izveštaja omogućava sagledavanje efikasnosti korišćenja kapitala od strane menadžmenta konkretnih entiteta. Navedenom svrhom finansijskog izveštavanja ističe se značaj kvaliteta finansijskih izveštaja i u tom kontekstu bitnih karakteristika profesionalnih računovođa koje sastavljaju finansijske izveštaje.

Računovodstvenu profesiju određuju bitna obeležja, kao što su: posedovanje određenih intelektualnih sposobnosti i praktičnih veština, stečenih odgovarajućim stručnim obrazovanjem i obukom; zatim, pridržavanje članova profesije zajedničkog kodeksa vrednosti i ponašanja; i prihvatanje obaveza članova profesije prema asocijacijama, poslodavcima i društvu u celini, uz nastojanje harmonizacije ličnih interesa sa obavezama i širim interesima profesije. Takođe bitna karakteristika računovodstvene profesije jeste i odgovornost prema javnosti, povodom koje profesionalne računovođe imaju značajnu ulogu u privredi i društvu uopšte, naročito izraženu u interesima ulagača, kreditora, poverilaca, poslodavaca, menadžmenta, zaposlenih eksperata i izvršilaca, vladinih institucija, aktuelnih i budućih poslovnih partnera, kao i stručne i šire javnosti. $\mathrm{U}$ tom smislu, $\mathrm{u}$ interesu računovodstvene profesije je da, $\mathrm{u}$ cilju zaštite sopstvene odgovornosti koja je usmerena prema različitim interesnim grupama (računovodstveno-finansijski menadžeri, menadžment i konsultanti iz upravljačkog računovodstva, nezavisni i interni revizori, portfolio menadžeri, poreski eksperti i konsultanti), svoje profesionalne usluge pružaju, u potpunosti u skladu sa etičkim zahtevima i očekivanjima korisnika usluga i šire javnosti.

Etičkim kodeksom za profesionalne računovođe definisani su osnovni ciljevi i principi računovodstvene profesije. Ciljevi računovodstvene profesije prema Kodeksu su da u svojoj ukupnosti ova profesija funkcioniše u skladu sa zahtevima javnog interesa prema najvišim profesionalnim standardima. Ključne etičke vrednosti za računovodstvenu profesiju u opštem smislu su poverenje (povezano sa njim: poštenje, integritet, lojalnost), čestitost (počiva na: dostojanstvu, uljudnosti, tolerantnost i sposobnost usaglašavanja); odgovornost (vršenje aktivnosti na najbolji način uz respektovanje potencijalnih posledica), fer odnos i pravičnost (ravnopravan odnos prema ljudima i pojavama, nepristrasnost $\mathrm{i}$ iskrenost, kao i primeren odnos prema činjenicama), privrženost poslu i civilizovano ponašanje (poštovanje propisa i pošteno obavljanje aktivnosti povezanih sa društvenim interesom).

Zbog činjenice da finansijski izveštaj često ima za cilj da poveže aktuelnog i potencijalnog investitora sa poslovnim subjektom koji koristi kapital, može se zaključiti da je uloga računovođe naročito značajna u tržišno orijentisanim privredama.

Pošto je osnovna uloga računovođa da predstavljaju budne čuvare tržišta odnosno lica koja traže i čuvaju istinu, suštinske vrline $e^{24}$ profesionalnog računovođe se ne menjaju od nastanka računovodstvene profesije do danas, a to su: odlučnost, hrabrost i trvdoglavost, dok bi njihova osnovna mana mogla da bude pohlepa.

Svi učesnici u procesu finansijskog izveštavanja, uključujući i menadžment, u okviru svog delokruga rada treba

24 Mark Šefers, Majkl Pakaluk, Razumevanje računovodstvene etike, str. 98, Vrline mogu da imaju karakter intelektualnih vrlina-karakteristika koje nam omogućavaju da dođemo do spekulativne istine (mudrost) i karakternih vrlina-karakteristika koje nam omogućavaju da postignemo praktičnu istinu (pravednost, hrabrost, gospodarenje sobom). 
da insistiraju na poštovanju etičkih principa; da identifikuju neetičko ponašanje; procenjuju njegove efekte na kvalitet finansijskog izveštavanja i određuju odgovarajuće mere zaštite, u cilju unapređenja etičkog ponašanja.

Posledice neetičkog ponašanja profesionalnih računovođa mogu da se kvantifikuju u iznosu: troškova plaćenih kazni i penala; troškova naknadnog, odnosno ponovnog sastavljanja finansijskih izveštaja; troškova korekcije grešaka u finansijskim izveštajima; troškova dodatnog angažovanja revizora; troškova supervizije i ostalih sličnih troškova. Međutim, za razliku od vrednosno merljivih posledica vrednosno merljivih troškova, vrednosno nemerljive posledice neetičkog ponašanja profesionalnih računovođa mogu da imaju daleko veće efekte, kao što su: gubitak reputacije i ugleda računovođa, menadžmenta, kao i poslovnog subjekta u celini. Pored toga, posledice mogu biti i pad tržišne cene akcija, odnosno loše kotiranje poslovnog subjekta na berzi, smanjenje vrednosti učešća investitora, gubitak klijenata i poslovnih partnera, loš glas, pogoršanje poslovne klime, nezainteresovanost investitora za ulaganjem i kreditora za kreditiranjem, kumuliranje finansijkih teškoća, ugrožavanje likvidnosti i solventnosti.

Prema tome, dobra etička klima u poslovnom subjektu teško da se može organizovati bez postojanja etičkog kodeksa, koji je potreban ali ne i dovoljan uslov, jer bez razvijene moralne i etičke svesti zaposlenih, zatim bez upoznavanja sa etičkim zahtevima i sankcijama nepridržavanja, kao i bez nadzora i kontrole od strane profesionalnih tela, nema dobre etičke klime. Kodeks predstavlja samo polaznu osnovu, on takođe treba da upućuje na određena pitanja koja nisu njime direktno tretirana, u smislu opšte sfere etičkog ponašanja.

\section{LITERATURA}

EUR-Lex. (2013). Directive 2013/34/EU of the European Parliament and of the Council of 26 June 2013. Preuzeto sa http://eur-lex. europa.eu/legal-content/EN/TXT/?uri=celex:32013L0034

IFAC. (2010). 2010 Handbook of the Code of Ethics for Professional Accountants. New York: International Federation of Accountants.

IFAC. (2010). 2010 Handbook of the Code of Ethics for Professional Accountants. New York: International Federation of Accountants.

Milojević, D. (2007). Finansijska revizija i kontrola. Beograd: Beogradska poslovna škola.

Malinić, S. (2007). Međunarodna obrazovna regulativa za profesionalne računovođe. Simpozijum SRRS, Zaltibor.

Malinić, S. (2008). Profesionalna etika i edukacija u funkciji kvaliteta finansijskog izveštavanja. 39 Simpozijum SRRS, Zaltibor.

Novićević, B. (2007). Ključni principi profesionalne etike za finansijsko izveštavanje. 37. Simpozijum SRRS, Zaltibor, 2007.

Stojanović Rada, Profesionalni računovođa - imperativ kavliteta finansijskog izveštavanja, 42. Simpozijum SRRS, Zaltibor, 2011.

Stojanović, R. (2014). Efekti Direktive Evropske unije 20134/34 na finansijsko izveštavanje. Računovodstvo, 1-2/2014. Beograd: SRRS.

Stojanović, R. (2010). Međunarodni standardi finansijskog izveštavanja. Beograd: Savez računovođa i revizora Srbije.

Službeni glasnik RS. (2013). Zakon o računovodstvu. Sl. glasnik RS, br. 62/13.

Šefers, M., \& Pakaluk, M. (2009). Razumevanje računovodstvene etike. Beograd: Službeni glasnik.

Škarić-Jovanović, K. (2012). Posledice primene različitih računovodstvenih politika pri naknadnom vrednovanju materijalnih ulaganja. 7. Kongres računovođa i revizora Crne Gore, Bečići.

Škobić, Z. (2011). IFAC-ov Etički kodeks za profesionalne računovođe. Beograd: Savez računovođa i revizora Srbije.

\section{PROFESSIONAL ETHICS AS AN IMPERATIVE OF RELIABILITY OF FINANCIAL REPORTING}

\begin{abstract}
:
The quality of financial statements as a crucial factor of information support to management and decision-making process of investors and other users of financial statements depends on the accounting standards, legislation, control of implementation of accounting standards and legislation, education of professional accountants, accounting profession, ethics and auditing standards. The main purpose of financial statements is to disclose true information on financial situation and performances of an entity, which ensures public trust as an important indicator of market economy, i.e., effective planning and use of capital. An accountant takes on multiple roles in modern business conditions, including recording of business transactions and financial statement preparation, analysis of financial statements, providing advice to management about the operations with securities, tax advice, achieving comparative advantage, managing financial crisis and minimizing business risks, i.e., the role of a professional accountant is oriented more towards integrated financial reporting. The complexity of the role of a professional accountant in the environment in which money is the main priority, can be understood only through full commitment to ethics, i.e., compliance with the Code of Ethics for Professional Accountants. Bearing that in mind, this paper shall highlight only the key principles of ethical behaviour of professional accountants.
\end{abstract}

\section{Key words:}

professional ethics, professional accountant, accounting regulation, legislation, public interest. 